\title{
PENGARUH MODEL PEMBELAJARAN POGIL BERBANTUAN MEDIA PERMAINAN TTS TERHADAP HASIL BELAJAR IPA SISWA KELAS V SD
}

\author{
Ni Md. Tini Sulasmi ${ }^{1}$ Ni Wy. Rati ${ }^{2}$ I Gst. Ngurah Japa ${ }^{3}$ \\ 1,2,3 Jurusan Pendidikan Guru Sekolah Dasar, Universitas Pendidikan Ganesha, \\ Singaraja \\ e-mail: ni.made.tini.sulasmi@undiksha.com ${ }^{1}$, niwayan.rati@undiksha.ac.id ${ }^{2}$, \\ ngrjapa_pgsd@yahoo.id ${ }^{3}$
}

\begin{abstract}
Abstrak
Penelitian ini bertujuan untuk mengetahui pengaruh model pembelajaran POGIL berbantuan media permainan teka-teki silang (TTS) terhadap hasil belajar IPA siswa kelas V SD di Gugus IV Cempaka Putih Kecamatan Kubutambahan Kabupaten Buleleng tahun pelajaran 2017/2018. Jenis penelitian ini yaitu eksperimen semu dengan rancangan post test only control group design. Populasi penelitian ini adalah siswa kelas V SD di Gugus IV Cempaka Putih tahun pelajaran 2017/2018 yang berjumlah 168 siswa. Penentuan sampel dilakukan dengan teknik random sampling. Instrumen pengumpulan data dalam penelitian ini adalah tes objektif. Data yang diperoleh dianalisis dengan analisis statistik deskriptif, uji prasyarat analisis data, dan uji hipotesis melalui uji-t. Hasil penelitian menunjukkan bahwa terdapat perbedaan yang signifikan hasil belajar IPA antara kelompok siswa yang dibelajarkan dengan model pembelajaran POGIL berbantuan media permainan TTS dan kelompok siswa yang tidak dibelajarkan dengan model pembelajaran POGIL berbantuan media permainan TTS. Hal ini dilihat dari hasil perhitungan uji-t diperoleh $t_{\text {hitung }}=5,103$ dan $t_{\text {tabel }}=2,012$ ( $\left.t_{\text {hitung }}>t_{\text {tabel }}\right)$. Adanya perbedaan terhadap hasil belajar IPA siswa menandakan bahwa model pembelajaran POGIL berbantuan media permainan TTS berpengaruh positif terhadap hasil belajar IPA siswa.
\end{abstract}

Kata kunci: POGIL, teka-teki silang, hasil belajar IPA

\begin{abstract}
This study aimed at determining the effect of learning model POGIL assisted by crossword puzzle game media toward the learning outcome of natural science grade $V$ primary students in Cluster IV Cempaka Putih, Kubutambahan Sub-district, Buleleng Regency in academic year 2017/2018. This research type was quasi experiment with post test only control group design. The population of this research were the students of grade V of primary school in Cluster IV Cempaka Putih, in academic year 2017/2018 amounting to 168 students. Sample determination was done by random sampling through lottery technique. The instrument of data collection used in this research was objective test. The data obtained were analyzed by descriptive statistical analysis, prerequisite test of data analysis, and hypothesis test through t-test. The results showed that there were significant differences of learning outcome of natural science between groups of students who were taught by POGIL learning model assisted by the media of crossword puzzle and groups of students who were not taught by the learning model of POGIL assisted by the media of crossword puzzles. It was seen from result of $t$-test calculation obtained $t_{\text {count }}$ $=5,103$ and $t_{\text {table }}=2.012\left(t_{\text {tcount }}>t_{\text {table }}\right)$. The differences in the learning outcome of natural science students indicated that the POGIL learning model assisted by crossword puzzle media had a positive effect on learning outcome of natural science on students.
\end{abstract}

Keywords: POGIL, crossword puzzle, learning outcome of natural science 


\section{Pendahuluan}

Sekolah dasar (SD) merupakan tingkat satuan pendidikan yang dianggap sebagai dasar pendidikan. IImu pengetahuan alam (IPA) merupakan salah satu mata pelajaran yang harus dikuasai oleh peserta didik di sekolah dasar. IPA merupakan mata pelajaran wajib di sekolah dasar. Hal ini senada dengan pendapat Susanto (2013) yang menyatakan bahwa IPA merupakan salah satu mata pelajaran pokok pada jenjang sekolah dasar. IPA dapat dibagi menjadi tiga, yaitu IPA sebagai produk, proses, dan sikap. Salah satu cara agar pembelajaran IPA dapat mencangkup tiga komponen IPA, maka dalam pembelajaran IPA di sekolah dasar hendaknya dilakukan melalui pengamatan-pengamatan sederhana yang berbasis proses dan bukan berdasarkan hafalan terhadap konsep IPA.

Kegiatan pengamatan atau penyelidikan sederhana dalam proses pembelajaran IPA, memberikan pengalaman belajar yang bermakna bagi siswa dan siswa dapat menemukan sendiri konsep IPA yang nantinya tersimpan lebih lama dalam ingatan siswa. Hal ini dikarenakan pembelajaran dengan kegiatan pengamatan dapat meningkatkan aktivitas belajar siswa. Siswa aktif terlibat untuk mencari dan menemukan sebuah pengetahuan (Butudoka, 2016).

Kenyataannya kondisi yang ada pada saat ini justru sebaliknya, proses pembelajaran di sekolah dasar memiliki kecenderungan pada metode tertentu dan tidak memperhatikan tingkat pemahaman siswa terhadap informasi yang disampaikan. Siswa kurang aktif dalam proses pembelajaran, siswa lebih banyak mendengar dan menulis yang mengakibatkan isi pelajaran sebagai hafalan, yang tidak bertahan lama dalam ingatan siswa. Terlebih lagi guru jarang membuat ataupun menggunakan media pembelajaran, sehingga siswa kurang tertarik mengikuti proses pembelajaran. Hal ini mengakibatkan hasil belajar IPA siswa cenderung rendah. Hasil belajar IPA merupakan perubahan tingkah laku pada siswa yang terjadi sebagai hasil dari kegiatan belajar IPA. Perubahan tingkah laku sebagai hasil belajar IPA mengacu pada IPA sebagai produk, proses, dan sikap ilmiah.

Salah satu sekolah yang ditemukan mengalami masalah dalam pembelajaran IPA adalah sekolah dasar (SD) yang ada di Gugus IV Cempaka Putih Kecamatan Kubutambahan Kabupaten Buleleng. Berdasarkan hasil wawancara yang telah dilakukan diperoleh informasi bahwa hasil belajar IPA siswa cenderung masih rendah. Beberapa guru mengakui bahwa dalam proses pembelajaran IPA jarang menggunakan model pembelajaran yang berpusat pada siswa (student centered). Selain itu, beberapa guru juga menyatakan bahwa dalam pembelajaran IPA sangat jarang melakukan percoban/pengamatan untuk menemukan sebuah konsep dari materi ajar.

Setelah melakukan wawancara, selanjutnya dilakukan kegiatan observasi. Berdasarkan hasil observasi diperoleh fakta bahwa siswa menerima informasi hanya ketika guru menyampaikan materi sedangkan siswa duduk pasif sebagai pendengar. Aktivitas siswa dalam proses pembelajaran IPA masih kurang, proses pembelajaran masih didominasi oleh guru atau dapat dikatakan pembelajaran masih berpusat pada guru (teacher centered). Guru jarang memberikan permasalahan yang berkaitan dengan materi sehingga siswa tidak mempunyai kesempatan untuk aktif berpikir dan menemukan sendiri jawaban dari permasalahan yang ada sesuai dengan materi ajar IPA. Di samping itu, guru cenderung jarang membuat dan menggunakan media pembelajaran yang menyebabkan siswa kurang tertarik mengikuti proses pembelajaran, ketika siswa sudah tidak tertarik mengikuti proses pembelajaran maka pembelajaran menjadi tidak menyenangkan dan siswa tidak fokus mengikuti pembelajaran. Kurangnya penerapan media pembelajaran mengakibatkan siswa malas mendengarkan penjelasan guru, siswa mengantuk dan lebih memilih untuk bermain dengan teman sebangkunya, ataupun membuat coretan-coretan yang tidak penting dibangkunya saat guru menjelaskan materi.

Informasi yang telah diperoleh saat wawancara, terkait hasil belajar IPA siswa cenderung rendah dibuktikan dengan hasil studi dokumentasi yang dilakukan pada tanggal 11-13 Desember 
2017 diketahui bahwa memang benar hasil belajar IPA siswa kelas V SD di Gugus IV Cempaka Putih Kecamatan Kubutambahan Kabupaten Buleleng cenderung masih rendah. Hal ini dapat dibuktikan dari data nilai tes ulangan akhir semester ganjil, mata pelajaran IPA kelas $\mathrm{V}$ dengan jumlah siswa secara keseluruhan 168 siswa, namun sebanyak $71,42 \%$ siswa dengan nilai masih di bawah KKM.

Berdasarkan hasil observasi dan wawancara yang telah dilakukan diduga yang menyebabkan kecenderungan lebih banyak siswa kelas V SD di Gugus IV Cempaka Putih Kecamatan Kubutambahan Kabupaten Buleleng mendapatkan nilai di bawah KKM adalah sebagai berikut. (1) Proses pembelajaran IPA hanya terjadi dalam satu arah, yaitu dari guru kepada siswa saja, dalam artian aktivitas siswa dalam proses pembelajaran IPA masih kurang, proses pembelajaran lebih didominasi oleh guru. (2) Penyelidikan-penyelidikan sederhana untuk menemukan sebuah konsep materi ajar IPA jarang dilakukan, sehingga pembelajaran menjadi kurang bermakna dan informasi yang diperoleh tidak bertahan lama dalam ingatan siswa. (3) Media pembelajaran sebagai alat bantu untuk mengkomunikasikan materi yang digunakan guru juga sangat kurang. (4) Guru jarang menggunakan model pembelajaran yang berpusat pada siswa (student centered). Selain itu model pembelajaran yang digunakan kurang bervariasi, model yang sama secara rutin digunakan oleh guru, sehingga menimbulkan kebosanan siswa untuk mengikuti pembelajaran di kelas.

Berdasarkan permasalahan di atas, perlu adanya upaya untuk memperbaiki proses pembelajaran IPA di sekolah dasar. Salah satu upaya yang dapat dilakukan oleh guru adalah melakukan perubahan dalam proses pembelajaran. Perubahan yang dimaksud yaitu mencakup perubahan peran guru dalam pembelajaran, perubahan orientasi pembelajaran, dan perubahan ruang lingkup pembelajaran. Salah satu model pembelajaran yang dapat mengakomodasikan ketiga perubahan tersebut adalah model pembelajaran POGIL. POGIL merupakan singkatan dari Proses Oriented Guided Inquary Learning. Model pembelajaran POGIL merupakan salah satu model pembelajaran inkuri terbimbing yang berbasis proses.

Shimonson dan Shadle (2013:57) mengungkapkan bahwa, "key to the effectiveness of POGIL is the guided inquiry classroom activity". Model pembelajaran POGIL merupakan elaborasi dari tiga komponen, yaitu tim belajar, aktivitas inkuiri terbimbing, dan metakognisi. Ketiga komponen tersebut dikemas melalui siklus belajar yang terdiri dari tiga fase yaitu eksplorasi, penemuan konsep, dan aplikasi (Hanson, 2006). Pada fase eksplorasi, siswa diminta untuk mengeluarkan seluruh pengetahuan awalnya terkait dengan materi yang akan dibahas. Hal ini terjadi karena pada fase ini siswa dihadapkan pada suatu permasalahan atau pertanyaan yang diajukan oleh guru. Siswa berusaha menanggapi permasalahan yang diberikan tersebut berdasarkan pengetahuan awal yang dimiliki siswa. Pembentukan kelompok-kelompok belajar juga dilaksanakan pada fase ini.

Fase penemuan konsep merupakan fase kedua pada model pembelajaran POGIL. Fase ini memungkinkan siswa untuk mengenal istilah-istilah baru terkait materi yang akan dipelajari. Guru memberikan suatu masalah yang memungkinkan siswa untuk menemukan dan membentuk konsep yang ada pada materi yang dipelajari. Siswa dituntun oleh guru untuk belajar dalam kelompok kecilnya masing-masing dan berdiskusi menemukan konsep dari materi ajar, sehingga nantinya siswa diharapkan mampu membuat suatu simpulan dari hasil diskusinya. Setelah simpulan dibuat pada fase penemuan konsep, selanjutnya masuk ke fase aplikasi. Fase aplikasi adalah fase penerapan konsep yang telah dipelajari yang dapat meningkatkan pemahaman siswa terhadap materi. Hal ini didukung oleh pendapat Umam, dkk (2016) yang menyatakan bahwa pada tahap pengaplikasian konsep menyebabkan pemahaman siswa lebih mendalam. Pemahaman yang mendalam ini menyebabkan daya ingat siswa terhadap materi yang telah dipelajari bertahan lebih lama.

Keefektifan model pembelajaran POGIL pernah diterapkan dalam penelitian yang dilakukan oleh Sulastriningsih (2013), Marcelia (2016), Mahayana (2016), dan Yuliani (2017) hasil 
penelitiannya menunjukkan bahwa model pembelajaran POGIL mampu meningkatkan kemampuan pemahaman konsep IPA siswa, keterampilan proses sains, dan mampu meningkatkan hasil belajar IPA siswa.

Untuk mendukung model pembelajaran yang sudah relevan, digunakan bantuan berupa media pembelajaran. Media pembelajaran yang digunakan dalam penelitian ini yaitu media pembelajaran berupa permainan. Bagi anak, sebagian besar kegiatan mereka dilakukan dengan bermain-main. Mereka bisa menyerap unsur-unsur pembelajaran yang terkandung dalam bentuk permainan. Media permainan yang dipilih adalah permainan teka-teki silang (TTS). Teka-teki silang merupakan sebuah permainan yaitu mengisi ruang-ruang kosong yang berbentuk kotak dengan huruf-huruf sehingga membentuk sebuah kata yang sesuai dengan petunjuk (Khalilullah, 2012). Mengisi TTS berguna untuk mengingat kosa kata yang populer dan berguna juga untuk pengetahuan yang bersifat umum dengan cara santai. Media permainan TTS dapat memotivasi siswa agar lebih semangat dan tidak bosan mengikuti proses pembelajaran. Hal ini didukung oleh pendapat Haryono (dalam Rantika dan Abdulah, 2015) yang menyatakan bahwa dalam TTS terdapat unsur permainan yang dapat menimbulkan kegairahan dan rasa senang dalam belajar tanpa harus berhadapan dengan situasi yang membosankan. Kondisi pikiran yang jernih, rileks, dan tenang membuat memori otak kuat, sehingga daya ingat pun meningkat (Rantika dan Abdulah, 2015). Dengan menggunakan media permainan TTS dapat menciptakan suasana lingkungan belajar menjadi lebih menyenangkan, bermakna, dan tidak membosankan. Semua siswa terlibat langsung dalam permainan yang mendidik.

Tujuan dari penelitian ini adalah untuk mengetahui pengaruh model pembelajaran POGIL berbantuan media permainan teka-teki silang (TTS) terhadap hasil belajar IPA pada siswa kelas V SD di Gugus IV Cempaka Putih Kecamatan Kubutambahan Kabupaten Buleleng Tahun Pelajaran 2017/2018.

\section{Metode}

Penelitian ini merupakan penelitian kuasi eksperimen yang dilaksanakan di Gugus IV Cempaka Putih, Kecamatan Kubutambahan dengan jumlah populasi 168 siswa. Penelitian ini menggunakan rancangan non equivalent post-test only control group design. Pengambilan sampel pada penelitian ini dilakukan dengan teknik group random sampling, dengan teknik ini dapat ditentukan satu kelas eksperimen yaitu SD Negeri 3 Depeha dan satu kelas sebagai kelas kontrol yaitu SD Negeri 2 Depeha. Data yang dikumpulkan dalam penelitian ini yaitu data hasil belajar IPA siswa kelas V SD. Pengumpulan data dalam penelitian ini dilakukan dengan metode tes. Instrumen yang digunakan untuk memperoleh data tentang hasil belajar IPA dalam penelitian ini berupa tes objektif (pilihan ganda) dengan satu jawaban benar yang berjumlah 30 butir soal.

Sebelum tes digunakan untuk penelitian, tes yang telah disusun diuji coba terlebih dahulu, setelah itu dilanjutkan dengan uji validitas, uji reliabilitas tes, uji taraf kesukaran butir tes, dan uji daya tes. Setelah melaksanakan tes dan mendapatkan data maka dilanjutkan dengan melakukan analisis data. Teknik analisis data yang digunakan dalam penelitian ini yaitu analisis statistik deskriptif, uji prasyarat data, dan uji hipotesis melalui uji-t sampel independen tak berkolerasi .

\section{Hasil dan pembahasan}

Hasil belajar IPA pada kelompok siswa yang dibelajarkan dengan model pembelajaran POGIL berbantuan media permainan TTS atau kelompok eksperimen yang berjumlah 25 orang menunjukkan bahwa skor tertinggi adalah 28 dan skor terendah adalah 12 dengan mean $(\mathrm{M})=$ 21,92; median $(\mathrm{Md})=22,63$; modus $(\mathrm{Mo})=22,90(\mathrm{Mo}>\mathrm{Md}>\mathrm{M})$. Modus, median, dan mean hasil belajar IPA siswa selanjutnya disajikan ke dalam kurva poligon. Tujuan dari penyajian data ini 
adalah untuk memudahkan pengamatan tentang sebaran data modus, median, dan mean hasil belajar IPA siswa pada kelompok eksperimen. Data hasil belajar IPA kelompok eksperimen dapat disajikan ke dalam bentuk kurva poligon seperti pada Gambar 1 berikut ini

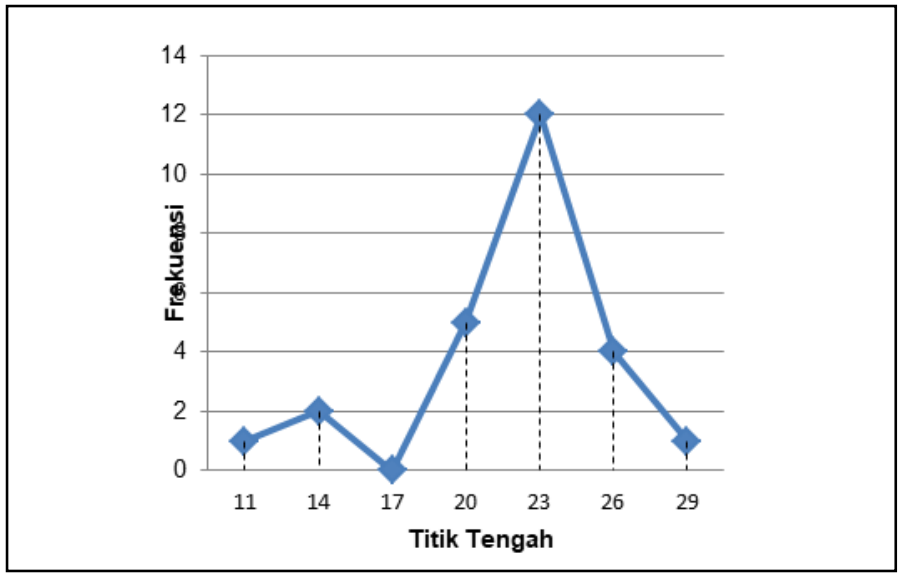

Gambar 1. Kurva Poligon Data Hasil Post Test Kelompok Eksperimen

Berdasarkan Gambar 1, tampak bahwa kurva berbentuk juling negatif yang berarti sebagian besar skor hasil belajar IPA siswa cenderung tinggi. Rata-rata skor atau mean hasil belajar IPA siswa kelompok eksperimen adalah 21,92. Apabila dikonversikan pada Skala Lima Teoritik, mean atau rata-rata skor hasil belajar IPA siswa pada kelompok eskperimen berada pada kategori tinggi.

Berbeda dengan hasil belajar IPA siswa pada kelompok kontrol yang berjumlah 32 orang. Skor tertinggi adalah 26 dan skor terendah adalah 8, dengan mean $(\mathrm{M})=16,28$; median $(\mathrm{Md})=$ 15,63; modus $(\mathrm{Mo})=13,21$ (Mo<Md<M). Modus, median, dan mean hasil belajar IPA siswa selanjutnya disajikan ke dalam kurva poligon. Tujuan dari penyajian data ini adalah untuk memudahkan pengamatan tentang sebaran data modus, median, dan mean hasil belajar IPA siswa pada kelompok kontrol. Data hasil belajar kelompok kontrol dapat disajikan ke dalam bentuk kurva poligon seperti pada Gambar 2 berikut ini.

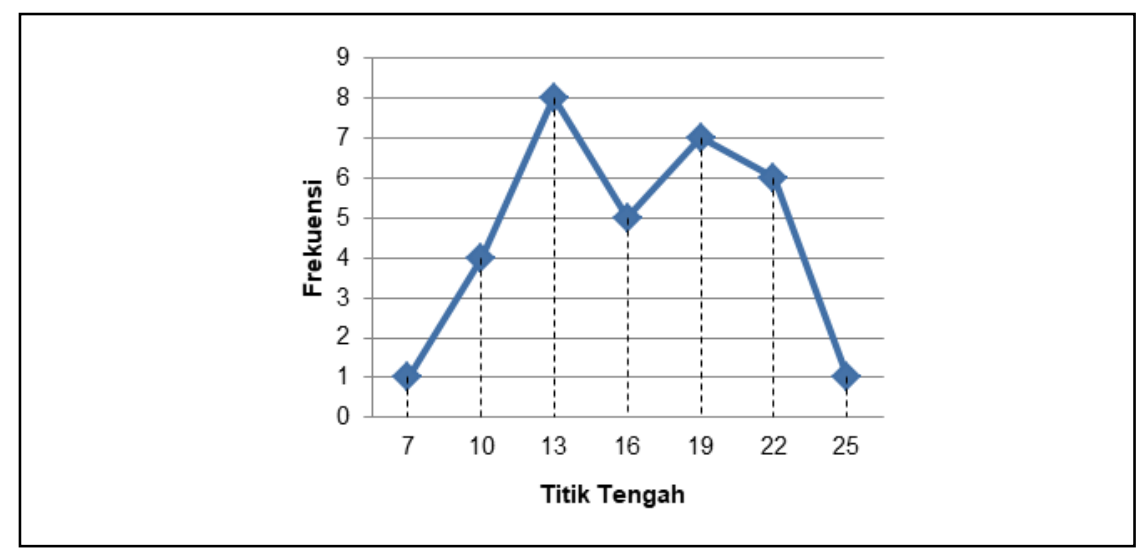

Gambar 2. Kurva Poligon Data Hasil Post Test Kelompok Kontrol

Berdasarkan Gambar 2, tampak bahwa kurva berbentuk juling positif yang berarti sebagian besar skor hasil belajar IPA siswa cenderung rendah. Rata-rata skor hasil belajar IPA siswa 
kelompok kontrol adalah 16,28. Apabila dikonversikan pada Skala Lima Teoritik, Mean atau ratarata skor hasil belajar IPA siswa pada kelompok kontrol berada pada kategori sedang.

Selain melakukan analisis deskriptif data, analisis yang dilakukan selanjutnya yaitu uji prasyarat. Uji prasyarat yang dilakukan yaitu uji normalitas sebaran data dan uji homogenitas varians. Hasl uji normalitas pada kelompok eksperimen dan kelompok kontrol diketahui bahwa $x^{2}{ }_{\text {hitung }}$ kelompok eksperimen 7,16 dan $x^{2}{ }_{\text {hitung }}$ kelompok kontrol 1,69 $<x^{2}$ tabel 11,07 (pada taraf signifikansi 5\%) sehingga data hasil belajar IPA siswa kelompok eksperimen dan kelompok kontrol berdistribusi normal. Sedangkan hasil uji homogenitas varians menunjukkan bahwa nilai $F_{\text {tabel }}$ (pada taraf signifikansi $\left.5 \%\right)>F_{\text {hitung }}(4,02>1,30)$, sehingga dapat disimpulkan bahwa varians data kedua kelompok homogen. Setelah uji prasyarat terpenuhi, maka dilanjutkan ke-uji hipotesis, uji hipotesis menggunakan independent sample t-test (tidak berkorelasi) dengan rumus polled varians karena jumlah siswa antara kelompok kontrol dan kolompok eskperimen berbeda dan data homogen. Ringkasan hasil uji hipotesis dapat disajikan pada Tabel 1 sebagai berikut.

Tabel 1. Ringkasan Hasil Uji Hipotesis

\begin{tabular}{lcccccc}
\hline $\begin{array}{l}\text { Data Hasil } \\
\text { Belajar IPA }\end{array}$ & Varians & $\bar{x}$ & $\mathrm{~N}$ & $\mathrm{t}_{\text {hitung }}$ & $\mathrm{t}_{\text {tabel }}$ & Keputusan \\
\hline K. Eksperimen & 14,64 & 21,92 & 25 & 5,103 & 2,012 & $\mathrm{H}_{1}$ Diterima \\
K. Kontrol & 19,087 & 16,28 & 32 & & & \\
\hline
\end{tabular}

Berdasarkan Tabel 1, hasil uji hipotesis menunjukkan bahwa $t_{\text {hitung }}>t_{\text {tabel }}(5,103>2,012)$, sehingga $\mathrm{H}_{0}$ ditolak dan $\mathrm{H}_{1}$ diterima.

\section{Pembahasan}

Berdasarkan deskripsi data hasil penelitian, diketahui bahwa hasil belajar IPA siswa yang dibelajarkan dengan model pembelajaran POGIL berbantuan media permainan TTS lebih tinggi dibandingkan dengan hasil belajar IPA siswa yang tidak dibelajarkan dengan model pembelajaran POGIL berbantuan media permainan TTS. Adanya perbedaan hasil belajar IPA dari kedua kelompok siswa, menunjukkan bahwa model pembelajaran POGIL berbantuan media permainan TTS berpengaruh signifikan terhadap hasil belajar IPA siswa, hal ini terjadi karena:

Pertama, pada fase eksplorasi dalam proses pembelajaran yang menerapkan model pembelajaran POGIL, guru membimbing siswa untuk mengeluarkan seluruh pengetahuan awalnya terkait dengan materi yang akan dibahas. Pada fase ini siswa dihadapkan pada suatu permasalahan atau pertanyaan yang diajukan oleh guru. Siswa berusaha menanggapi permasalahan yang diberikan tersebut berdasarkan pengetahuan awal yang dimiliki siswa. Selain itu pada fase ini, sebelum siswa melakukan sebuah eksperimen/percobaan sederhana, siswa berusaha menggali informasi bersama kelompok kecilnya dengan cara berdikskusi dengan kelompoknya ataupun dengan cara membaca buku ajar terkait dengan materi yang dipelajari. Kegiatan pembelajaran pada fase ini memberikan tantangan bagi siswa untuk aktif belajar dan berpikir kritis. Temuan ini sejalan dengan pendapat Hanson (2006) yang menyatakan bahwa pada tahap eksplorasi, siswa diminta untuk mengeluarkan seluruh pengetahuan awalnya terkait dengan materi yang akan dibahas.

Kedua, pada proses pembelajaran dengan model pembelajaran POGIL terdapat fase penemuan konsep. Pada fase penemuan konsep ini, siswa melakukan sebuah penyelidikan/eksperimen sederhana bersama kelompok kecilnya. Kemudian siswa berdiskusi dan bekerjasama dalam kelompok kecilnya untuk menyelesaikan sebuah masalah yang akan menuntun siswa menemukan konsep dari materi ajar yang dipelajari. Suasana diskusi siswa 
sangat kondusif, siswa yang kurang paham tidak malu untuk bertanya dengan rekan kelompoknya, anggota kelompok yang berkemampuan lebih membantu anggota kelompok yang memiliki kemampuan kurang, dengan demikian siswa merasa santai dan nyaman mengikuti proses pembelajaran. Selain itu, melalui kegiatan pembelajaran dengan melakukan percobaan sederhana dapat meningkatkan aktivitas siswa dalam proses pembelajaran karena semua siswa terlibat aktif dalam proses pembelajaran. Temuan ini sejalan dengan hasil penelitian Marcelia (2016) yang menyatakan bahwa dalam proses pembelajaran yang menerapkan model pembelajaran POGIL siswa aktif berkontribusi dalam pembelajaran, siswa diberikan kesempatan untuk menyelesaikan masalah yang telah diberikan. Semua siswa aktif berdiskusi, bertanya dan melakukan kegiatan percobaan. Pada saat melakukan percobaan sederhana, guru membimbing siswa agar siswa mampu menemukan konsep sesuai harapan guru. Guru dengan maksimal membimbing siswa dalam proses pembelajaran, agar tidak terjadi miskonsepi dalam menemukan sebuah konsep. Pada fase penemuan konsep, siswa juga dibimbing untuk membuat simpulan dan kemudian melaporkan hasil temuannya di depan kelas. Pada kegiatan ini sangat baik dalam melatih kemampuan siswa dalam berkomunikasi. Dengan demikian, percobaan yang telah mereka lakukan memberikan pengalaman belajar yang bermakna bagi siswa, dan konsep materi ajar IPA dapat diterima dengan baik oleh siswa, serta tersimpan lebih lama dalam ingatan siswa yang kemudian dapat meningkatkan hasil belajar IPA siswa.

Ketiga, pada siklus pembelajaran dengan model POGIL terdapat fase aplikasi atau penerapan konsep. Pada fase ini siswa menerapkan konsep yang telah meraka temukan dengan cara menjawab/menyelesaikan pertanyaan yang diberikan oleh guru yang bertujuan untuk menguji sekaligus meningkatkan pemahaman siswa terkait materi yang dipelajari. Hal ini senada dengan pendapat Umam, dkk (2016) yang menyatakan bahwa pada tahap pengaplikasian konsep menyebabkan pemahaman siswa lebih mendalam. Pemahaman yang mendalam ini dapat mengakibatkan daya ingat siswa bertahan lebih lama. Hal yang menarik dalam fase penerapan konsep ini adalah pertanyaan atau soal dikemas dalam bentuk permainan teka-teki silang (TTS). Pertanyaan/soal yang dikemas dalam bentuk permainan TTS mengakibatkan siswa lebih semangat dan tertarik untuk menjawab soal-soal, hal ini dikarenakan soal-soal yang dikemas dalam bentuk permainan memacu siswa untuk berkompetisi sehat antar kelompok dan menimbulkan rasa senang dalam belajar, sehingga apa yang dibahas mampu bertahan lama dalam ingatan siswa. Pernyataan mengenai soal-soal yang dikemas dalam bentuk TTS dapat menimbulkan rasa senang dalam belajar, didukung oleh pendapat Haryono (dalam Rantika dan Abdulah, 2015) menyatakan bahwa dalam TTS terdapat unsur permainan yang dapat menimbulkan kegairahan dan rasa senang dalam belajar tanpa harus berhadapan dengan situasi yang membosankan. Proses pembelajaran dengan menerapkan media permainan TTS dapat meningkatkan motivasi anak untuk terus semangat belajar guna mencapai hasil yang maksimal. Di samping itu, dalam penerapan permainan TTS menuntut siswa untuk berkompetisi yang sehat agar bisa menjadi pemenang dalam permainan. Bagi kelompok yang dapat mengisi teka-teki silang dengan cepat dan tepat maka akan mendapatkan reinforcement dari guru, begitu pula bagi kelompok yang tidak dapat mengisi TTS akan memperoleh hukuman berupa tantangan utuk menyanyikan sebuah lagu dengan gerakan-gerakan yang lucu. Adanya hadiah dan hukuman ini mampu membangkitkan semangat siswa, menggiring siswa untuk fokus mengikuti pembelajaran, mencipatakan pembelajaran yang menyenangkan, dan meningkatkan minat siswa untuk memahami materi ajar agar mampu mengisi TTS dan bisa menjadi pemenang. Dengan demikian, mengisi teka-teki silang sangat menyenangkan dan bermanfaat bagi siswa karena selain berguna untuk mengingat kosa kata yang populer, berguna juga untuk pengetahuan yang bersifat umum dengan cara santai. Pemahaman siswa terhadap materi juga bertahan lama dalam ingatan siswa karena suasana pembelajaran aktif dan ceria dengan permainan yang mendidik. Hal ini didukung oleh pendapat Randika dan Abdulah (2015) yang menyatakan bahwa sifat fun tetapi tetapi learning dari teka-teki silang memberikan efek menyegarkan ingatan, sehingga fungsi kerja otak kembali 
optimal karena otak dibiasakan untuk terus belajar dengan santai. Kondisi pikiran yang jernih, rileks, dan tenang akan membuat memori otak kuat, sehingga daya ingat pun meningkat.

Lain halnya dengan proses pembelajaran yang dilaksanakan di kelas kontrol yang tidak menerapkan model pembelajaran POGIL berbantuan media permainan TTS, siswa cenderung pasif dalam menggali pengetahuannya. Proses pembelajaran masih cenderung monoton dan proses pembelajaran masih didominasi oleh guru. Guru menjelaskan materi pembelajaran, kemudian siswa mendengarkan dan mencatat apa yang ditulis guru dipapan tulis dan terakhir melakukan tanya jawab kepada beberapa siswa yang dianggap sudah mengerti. Aktivitas siswa dalam pembelajaran masih cenderung rendah, banyak siswa yang terkadang berpura-pura membaca buku ketika guru meminta siswa memahami/mencari informasi terkait materi yang disampaikan guru di depan kelas. Selain itu dalam proses pembelajaran sering kali siswa merasa bosan dengan menunjukkan sikapnya yang melihat keluar dari kaca jendela kelas, melirik temannya kesana-sini, dan meletakkan telapak tangan di bawah dagunya. Hal ini menandakan siswa kurang tertantang untuk mengikuti proses pemelajaran. Media pembelajaran sebagai alat bantu untuk mengkomunikasikan materi yang digunakan guru juga sangat kurang sehingga siswa kurang tertarik untuk belajar dan siswa tidak fokus mengikuti proses pembelajaran. Terlebih lagi model pembelajaran yang digunakan kurang bervariasi, model yang sama secara rutin digunakan oleh guru, yang mengakibatkan siswa merasa bosan untuk mengikuti pembelajaran di kelas. Temuan ini sejalan dengan hasil penelitian Laksmi dkk (2014) yang menyatakan bahwa kurangnya variasi guru dalam menerapkan model pembelajaran dan pembelajaran masih didominasi oleh peran guru sebagai sumber utama pengetahuan merupakan permasalahan dalam kegiatan pembelajaran. Hal ini mengakibatkan siswa kurang memahami materi yang dipelajari dan kurang mendapatkan pengalaman belajar yang bermakna sehingga pengetahuan yang diperoleh tidak bertaha lama dalam ingatan siswa.

\section{Simpulan dan saran}

Berdasarkan paparan hasil penelitian dan pembahasan dapat dinyatakan bahwa terdapat perbedaan yang signifikan hasil belajar IPA antara siswa yang dibelajarkan dengan model pembelajaran POGIL berbantuan media permainan TTS dan siswa yang tidak dibelajarkan dengan model pembelajaran POGIL berbantuan media permainan TTS, hal ini dapat dibuktikan dari hasil uji hipotesis yang menunjukkan bahwa $t_{\text {hitung }} 5,103$ lebih besar dari $t_{\text {tabel }} 2,012$ sehingga $\mathrm{H}_{1}$ diterima. Adanya perbedaan yang signifikan menunjukkan bahwa model pembelajaran POGIL berbantuan media permainan TTS berpengaruh terhadap hasil belajar IPA siswa. Dengan demikian, dapat disimpulkan bahwa terdapat pengaruh yang signifikan model pembelajaran POGIL berbantuan media permainan teka-teki silang (TTS) terhadap hasil belajar IPA siswa kelas V SD di Gugus IV Cempaka Putih Kecamatan Kubutambahan Kabupaten Buleleng Tahun Pelajaran 2017/2018.

Berdasarkan simpulan di atas, disampaikan beberapa rekomendasi sebagai berikut. (1) Bagi kepala sekolah diharapakan dapat mengambil suatu kebijakan dalam membimbing dan memotivasi guru dalam memilih, merancang serta menerapkan model pembelajaran yang efektif dan kreatif di sekolah. (2) Bagi guru-guru di sekolah dasar diharapkan dapat menerapkan model POGIL berbantuan media permainan TTS dalam mata pelajaran IPA, namun tidak menutup kemungkinan model POGIL berbantuan media permainan TTS dapat diterapkan pada mata pelajaran lain, disesuaikan dengan kurikulum yang digunakan. Selain itu, guru-guru di sekolah dasar diharapkan juga agar lebih inovatif dan kreatif dalam menciptakan proses pembelajaran yang menarik, menantang, dan menyenangkan untuk dapat meningkatkan hasil belajar siswa. (3) Bagi siswa diharapkan agar aktif dan bersungguh-sungguh dalam mengikuti pembelajaran untuk mendapatkan pengalaman belajar yang bermakna sehingga dapat menerapkan konsep yang telah diperoleh dalam kehidupan sehari-hari. (4) Bagi peneliti selanjutnya yang akan melakukan 
penelitian terkait dengan model pembelajaran POGIL ataupun media TTS, disarankan agar dapat menggunakan hasil penelitian ini sebagai referensi dalam melakukan penelitian.

\section{Daftar pustaka}

Butudoka, Hartati Dj. 2016. "Penerapan Pengamatan Lingkungan Untuk Meningkatkan Hasil Belajar Siswa Pada Pembelajaran IPA di Kelas IV SDN 2 Labuan Lobo Kecamatan Ogodeide Kabupaten Tolitoli”. e Jurnal Kreatif Tadulako, Vol.4, No.3. Tersedia pada: http://jurnal. untad.ac.id/jurnal/ index.php/JKTO/article/view/3415. (diakses tanggal 14 November 2017).

Hanson, David M. 2006." Instructor's Guide to Process Oriented Guided Inquiry Learning". Stony Brook University-SUNY: Pacific Crest. Tersedia pada: https://pogil.org/uploads/media_items/pogil-instructor-sguide1.original.pdf (diakses tanggal 10 November 2017).

Khalilullah. 2012. "Permainan Teka-teki Silang Sebagai Media dalam Pembelajaran Bahasa Arab (Mufradat)". e-Journal Pemikiran Islam, Volume 37. Tersedia pada: http://ejournal.uinsuska.ac.id/index.php/Anida/article/viewFile/309/292 (diakses tanggal 20 November 2017).

Laksmi, Pt. K., dkk. 2014. "Pengaruh Model Pembelajaran Berbasis Otak (Brain Based Learning) Berbantuan Media Teka-teki Silang terhadap Hasil Belajar IPS Siswa Kelas V SD Gugus I Gusti Ngurah Jelantik". Jurnal Mimbar PGSD Universitas Pendidikan Ganesha, Vol. 2 No.1.Tersedia pada:http://download. portalgaruda.org/article.php?article=138746\&val=1342\&title=PENGARUH\%20MODEL\%20P EMBELAJARAN\%20BERBASIS\%200TAK\%20(\%20BRAIN\%20BASED\%20LEARNING\%20 \%20BERBANTUAN\%20MEDIA\%20TEKATEKI\%20SILANG\%20TERHADAP\%20HASIL\%20 BELAJAR\%20IPS\%20SISWA\%20KELAS\%20V\%20SD\%20GUGUS\%201\%20GUSTI\%20NG URAH\%20JELANTIK (diakses pada tanggal 21 Januari 2018).

Mahayana, I Made Helly, dkk. 2016. "Pengaruh Model Pembelajaran POGIL dan Minat Belajar Terhadap Pemahaman Konsep IPA Siswa Kelas IV".e-Jurnal PGSD Universitas Pendidikan Ganesha Jurusan PGSD, Vol. 4, No.1. Tersedia pada: http://ejournal.undiksha.ac.id/index.php/JJPGSD/article/ view/6976 (diakses tanggal 14 November 2017).

Marcelia, Ni Putu Widya. 2016. "Pengaruh Model Pogil Dan Minat Belajar Terhadap Keterampilan Proses Sains pada Siswa Kelas V Sd”. e-Jurnal PGSD Universitas Pendidikan Ganesha Jurusan PGSD, Vol. 4, No. 1. Tersedia pada: https://ejournal. undiksha.ac.id/index.php/JJPGSD/article/viewFile/6959/4749 (diakses tanggal 5 November 2017).

Rantika dan Faisal Abdulah. 2015. "Penggunaan Media Teka-teki Silang dalam Meningkatkan Hasil Belajar Siswa Kelas II pada Pembelajaran Bahasa Arab di Madrasah Ibtidaiyahnurul Iman Pengabuan Kabupaten Pali”. Tersedia pada: http://jurnal.radenfatah.ac.id/index.php/jip/article/download/522/472 (diakses tanggal 13 November 2017).

Shimonson, Shawn R. dan Susan E. Shadle. 2013. "Implementing Process Oriented Guided Inquiry Learning (POGIL) in Undergradute Biomechanics: Lessons Learned by A Novice". 
Journal of STEM Education, Volume 14. Tersedia pada: http://ojs.jstem.org/ index.php?journal=JSTEM\&page=article\&op=view\&path\%5B\%5D=1545 (diakses tanggal 13 November 2017).

Sulastriningsih, Pt. \& Kd. Suranata. 2012. "Pengaruh Model Process Oriented Guided InquiryLearning terhadap KemampuanPemahaman konsep IPA Siswa KelasV SD Gugus XI Kecamatan Buleleng". e-Journal Mimbar PGSD Universitas Pendidikan Ganesha Jurusan PGSD, No. 1 Tahun: 2012. Tersedia pada:http://ejournal.undiksha. ac.id/index.php/JJPGSD/article/view File/820/693 (diakses tanggal 13 November 2017).

Susanto, Ahmad. 2013. Teori Belajar dan Pembelajaran di Sekolah Dasar.

Umam, M. Syaikhul, dkk. 2016. "Pengaruh Model Process Oriented Guided Inquiry Learning (POGIL) terhadap Hasil Belajar dan Retensi Hasil Belajar Siswa pada Pembelajaran Fisika SMA/MA di Kabupaten Jember". Jurnal Pembelajaran Fisika, Volume 5, No. 3. Tersedia pada: http://download. portalgaruda.org/article.php?article=478762\&val=7717\&title=PENGARUH\%20MODEL\%20P ROCESS\%20ORIENTED\%20GUIDED\%20INQUIRY\%20LEARNING\%20(POGIL)\%20TERH ADAP\%20HASIL\%20BELAJAR\%20DAN\%20RETENSI\%20HASIL\%20BELAJAR\%20SISWA \%20PADA\%20PEMBELAJARAN\%20FISIKA\%20SMA/MA\%20DI\%20KABUPATEN\%20JEM BER (diakses tanggal 21 Januari 2017).

Yuliani, Ni Putu, dkk. 2017. "Pengaruh Model Pembelajaran POGIL Berbantuan Peta Pikiran Terhadap Hasil Belajar IPA Siswa Kelas V SD”. e-Journal Mimbar PGSD Universitas Pendidikan Ganesha Jurusan PGSD, Vol. 4, No. 2. Tersedia pada: https://ejournal. undiksha.ac.id/index.php/JET/article/view/11773 (diakses tanggal 14 November 2017). 